\title{
THE EFFECT OF PROBLEM SOLVING LEARNING MODEL BASED JUST IN TIME TEACHING (JiTT) ON SCIENCE PROCESS SKILLS (SPS) ON STRUCTURE AND FUNCTION OF PLANT TISSUE CONCEPT
}

\author{
Resha Maulida*, Nengsih Juanengsih, and Yuke Mardiati \\ Biology Education Study Program, State Islamic University Syarif Hidayatullah, Jakarta-Indonesia \\ *corresponding e-mail: resha.maulida923@gmail.com
}

\begin{abstract}
The purpose of this study was to determine the effect of Problem Solving learning model based Just in Time Teaching (JiTT) on students' science process skills (SPS) on structure and function of plant tissue concept. This research was conducted at State Senior High School in South Tangerang .The research conducted using the quasi-experimental with Nonequivalent pretest-Postest Control Group Design. The samples of this study were 34 students for experimental group and 34 students for the control group. Data was obtained using a process skill test instrument (essai type) that has been tested for its validity and reliability. Result of data analysis by ANACOVA, show that there were significant difference of postest between experiment and control group, by controlling the pretest score $(F=4.958 ; p<0.05)$. Thus, the problem-solving learning based on JiTT proved to improve students' SPS. The contribution of this treatment in improving the students' SPS was 7.2\%. This shows that there was effect of problem solving model based JiTT on students' SPS on the Structure and function of plant tissue concept.
\end{abstract}

Keywords: Just in time teaching, problem solving learning model, science process skills

(C) 2017 Department of Biology Education, FTTE, University of Muhammadiyah Malang, Indonesia

\section{INTRODUCTION}

The curriculum applicable in Indonesia since 2006 is the Education Unit Level Curriculum (in Indonesia known as Kurikulum Tingkat Satuan Pendidikan/KTSP). KTSP states that science is concerned with how to find out about nature systematically. Learning not only emphasizes students to master the various concepts of science, but also to teach them how to discover science.

In early 2013, curriculum changed, from KTSP to 2013 Curriculum. Although it get many criticisms, the change of curriculum is based on several reasons. One of the reasons is related to development of Science and Technology. Science subjects in the 2013 Curriculum at the elementary level are packaged thematically with other subjects, while at the intermediate level are packed in an integrated manner with science and attitude formation (Susilowati, 2013).

One thing that does not change in science subjects, both KTSP and 2013 Curriculum, is students are directed to develop the Science Process Skills (SPS). The students' SPS neet to be empowered. It is used as basis for them to be able to criticize the various issues related to the social and science phenomena aroun them. In addition, such learning will create an active learning environment.

Science can be interpreted as knowledge that has undergone truth testing through scientific method. The nature of science and science education can be viewed as a product, process, attitude, and application. Science as a product due to science consists of facts, laws, accepted theories (Zulfiani et al., 2009). Over time the science learning paradigm changes, from science as a product then turns into science as a process. In the latter paradigm, SPS is emphasized in learning.

SPS is a fundamental part of academic skills. In addition, SPS as "basic learning tools" is a basic skill that can develop the students' competency. The level of student's SPS is still less than $50 \%$, because the learning process is not empowering students' SPS (Haryono, 2006). This needs to be a concern as SPS is one of the basic skills that could maximize the selfcreation.

The nature of science as a process is one of reasons for a teacher to develop students' SPS. 
The other reason is relating to the future of their students. Socialization is needed on the importance of SPS developed, one of them because the community in the future will be a learning community that is learning to learn. Based on the results of school observation, it can be seen that SPS have not been fully considered in the learning process in the classroom or in the laboratory.

Rapid progress in science and technology causes a teacher no longer possible just to teach facts and concept. They must also develope their student skills i.e HOTS, problem solving, metacognition, and other $21^{\text {st }}$ Century skills during the student finding the knowledge (Fauzi et al., 2016; Husamah \& Pantiwati, 2014). Therefore, teacher must choose learning model that can follow the development of science and technology in generating student SPS.

One of the learning models recommended by the 2013 Curriculum is learning with problem solving. Problem solving is also one of the learning models that could empower students' SPS, which involves the basic skills of science in students. In addition, problem solving is based on constructivism paradigm, so students can develop their skills when build their own knowledge (Junaedi et al., 2008).

The interview result shows that the use of problem solving learning model is still difficult because it takes longer time for students to understand the problem posed. In the application of problem solving, firstly, students should recognize and understand the problem. So the weakness of the problem solving is if students do not have an understanding of the problem that is being studied, they will not learn what they want to learn. The way to overcome the situation is by utilizing technology as a source of information (Junaedi et al., 2008).

Education proccess in neighbouring countries, such as Malaysia and Singapore, have utilized various technologies. The condition makes both countries can be used as a good example as the good countries in organizing education. In indonesia, the utilization of internet in education has not developed rapidly. In Indonesia, the utilization of technology and information in the educational aspet is only $24 \%$. However, some education practitioners are beginning to see the prospect of utilizing the internet as an alternative in implementing distance education (Prawiradilaga et al., 2013).
One of the learning methods that utilize internet is Just in Time Teaching. Technology (JiTT)-based learning. JiTT have a characteristic that can be combined with any learning model. So, JiTT could incorporate with the problem solving syntax. Combining problem solving with JiTT is expected could improve students' SPS.

JiTT is a method and learning strategy that combines the use of information technology and active learning in the classroom. On of the characteristics of JiTT is the existence of feedback between students and teachers. Because there is feedback between teachers and students, it can be said that learning is students centered. Students can interact with teachers, with other students even with technology that can maximize students' thinking skills in the process of finding concepts (Solikhin, 2013).

Students should complete their web task before learning activity held in class if JiTT is chosen as learning method. The task will affect the students' learning in the classroom. Completing web tasks could improving students' readiness and retention (Mars et al., 2003).

The improvement of students' SPS will be optimal if students are actively involved in building their own concepts. Teachers function just as facilitators by using appropriate learning methods on material as well.

One of the material that can be selected to implement problem solving learning model based JiTT is the structure and function of plant tissue. Principles and applications on the material structure and function of this plant tissue is a conflict issue or controversial and concerned the interests of the people in society, for example in terms of plant tissue culture. So it is in accordance with the criteria of material selection in problem solving.

Learning model is also adapted to the basic competence on plant tissue structure material that presents data about tissue anatomy structure in plants based on the observation, then students are required to experiment using the process skills they have. But more students are introduced to dry or preserved preparations, so in the learning process less developing the students' science process skills.

The aim of this study is to determine the effect of problem solving learning model based JiTT on students' science process skills on structure and function of plant tissue concept. 


\section{METHOD}

The method used in this research was quasiexperimental with Nonequivalent PretestPostest Control Group Design (Sugiyono, 2013). The study was conducted at State High School in South Tangerang during the Odd semester of the academic year 2015/2016.

The population was all students from 5 classes of MIA (XI grade). Sampling was done by simple random sampling. Each class has the same opportunity to be a research sample. Samples taken were students from two classes of XI MIA, they were XI MIA 1 class (experimental group) and XI MIA 3 class (control group).

This research used two instruments that were essay test to measure the science process skill (12 items) with high category of reliability score (0.66). Observation sheets to observe students' skills during learning to measure student SPS.

In this study the data obtained from the science process skill test, ANACOVA was used to analyze statistic data. Hypothesis Testing Calculations in this study was also conducted using SPSS sofware version 20. Data obtained from the observation sheet were analyzed and then described.

\section{RESULTS AND DISCUSSION}

The average percentage of SPS pretest in both experimental and control groups was low, 34.78 for the experimental group and 40.65 for the control group (Table 1). The posttest results of both groups showed the highest achievement on the communication aspect (S4), as only a few students did not get the maximum score. Students in both groups were able to read their data and explain the results of the experiments. The lowest achievement in the experimental group was on the hypothesized aspect (S7); then designing the experiment (S8) is in moderate category. Students were still having difficulty in estimating the cause of something happening and determining the variables in the experiment (independent variable, dependent variable). Overall, the SPS in the experimental group was higher than the control group. The mean percentage of SPS posttest in the experimental group included the high category (79.86), while the mean percentage of SPS posttest in the control group was moderate (69.44).
Observations were conducted in the experimental and control groups using the observation sheet. In the observation sheet, there were 10 aspects related to SPS indicators. The SPS results from experimental group and control group observations are presented in Table 2.

The mean value of the student's SPS in the experimental group was higher than the student's mean score of SPS in the control group. The highest aspect of SPS in the experimental group was planning experiment and Observation with as Prediction with $66.67 \%$.

The highest aspect of SPS in the control group that was Classification and Communication with $83.33 \%$ of each aspect and the lowest SPS was predicting with $50.00 \%$. So the SPS in the experimental group was higher than the control group.

Based on prerequisite analysis of ANACOVA, it was seen that the interaction between the groups with pretest was not significant $(\mathrm{F}=0.178 ; \mathrm{p}<0.05)$. Thus, anova can be applied. Homogenity test results of postest data showed homogeneous, it was seen that the value of $F=1.104$ is not significant ( $p$ $<0.05$ ). Based on hypothesis test results, it can be seen that there were significant difference of postest between experiment and control group, by controlling the pretest score $(\mathrm{F}=4.958 ; \mathrm{p}$ $<0.05$ ). Thus, problem-solving learning based on JiTT proved able to improve the science process skills in the experimental class. The contribution of this treatment in improving the science process skills is $7.2 \%$.

The difference was influenced by the learning model applied to the two research groups, the problem solving learning model based JiTT in the experimental group while in the control group using problem solving learning model. Thus there was a significant influence of the use of problem-solving learning model based on JiTT on SPS in structure and function of plant tissue concept.

The use of problem solving learning model aims to improve the student's SPS. Based on the previous theory, it has been said that the problem solving learning model will better train students' ability to apply the learned theories to the new situation. Such ability in science can be interpreted as SPS, because SPS uses the process skills that students have to understand a concept or learn a concept. Previous research has shown that the use of problem solving 
learning model could improve SPS. In that previous research, the highest improvement is observation aspect (Hasanah, 2014).

Table 1. Percentage of science process skills (SPS)

\begin{tabular}{|c|c|c|c|c|c|c|c|c|}
\hline \multirow[b]{2}{*}{$\begin{array}{c}\text { SPS } \\
\text { Aspect }\end{array}$} & \multicolumn{4}{|c|}{ Experiment } & \multicolumn{4}{|c|}{ Control } \\
\hline & pretest & $\begin{array}{c}\text { SPS } \\
\text { category }\end{array}$ & posttest & $\begin{array}{c}\text { SPS } \\
\text { category }\end{array}$ & pretest & $\begin{array}{c}\text { SPS } \\
\text { category }\end{array}$ & posttest & $\begin{array}{c}\text { SPS } \\
\text { category }\end{array}$ \\
\hline S1 & 27.31 & very low & 78.75 & high & 45.38 & low & 73.95 & moderate \\
\hline $\mathrm{S} 2$ & 20.59 & very low & 90.20 & very high & 39.22 & low & 62.75 & moderate \\
\hline S3 & 24.51 & very low & 76.47 & high & 19.61 & very low & 58.82 & moderate \\
\hline S4 & 45.10 & low & 94.12 & very high & 91.18 & very high & 97.06 & very high \\
\hline S5 & 51.96 & low & 78.43 & high & 56.86 & moderate & 72.55 & moderate \\
\hline S6 & 33.33 & low & 86.27 & high & 30.39 & very low & 58.82 & moderate \\
\hline S7 & 16.91 & very low & 59.56 & moderate & 19.85 & very low & 51.47 & low \\
\hline S8 & 23.95 & very low & 66.39 & moderate & 16.81 & very low & 63.87 & moderate \\
\hline S9 & 34.56 & low & 76.47 & high & 20.59 & very low & 66.91 & moderate \\
\hline $\mathrm{S} 10$ & 69.61 & moderate & 92.16 & very high & 66.67 & moderate & 88.24 & high \\
\hline Average & 34.78 & low & 79.86 & high & 40.56 & low & 69.44 & moderate \\
\hline
\end{tabular}

Information: S1 observation, S2 applying concept, S3 classification, S4 communication, S5 interpretation, S6 prediction, S7 hypothesis, S8 planning experiment, S9 questioning, S10 using tools and material.

Table 2. Percentage of Student SPS Observation Results

\begin{tabular}{cccc}
\hline Aspect of SPS & $\begin{array}{c}\text { Experiment } \\
\text { Group (\%) }\end{array}$ & $\begin{array}{c}\text { Control } \\
\text { Group (\%) }\end{array}$ \\
\hline S1 & Observation & 91.67 & 75.00 \\
S2 & Applying & 75.00 & 66.67 \\
& concept & & \\
S3 & Classification & 75.00 & 83.30 \\
S4 & Communication & 91.67 & 83.33 \\
S5 & Interpretation & 75.00 & 66.70 \\
S6 & Prediction & 66.67 & 50.00 \\
S7 & Hypotheses & 75.00 & 66.67 \\
S8 & Planning & 91.67 & 75.00 \\
& experiment & & \\
S9 & Questioning & 83.33 & 58.33 \\
S10 & Using tools and & 77.80 & 61.10 \\
& materials & & 68.61 \\
\hline \multicolumn{4}{c}{ Average } \\
\hline
\end{tabular}

The use of JiTT could also increases the student's SPS because the JiTT model facililate the students to doing many activities, such as predicting, grouping, interpreting, applying, and communicating (Solikhin, 2013). Previous research also explained problem solving learning model based JiTT could maximize the effectiveness of class sessions, and students' learning time outside the classroom, while also creating and maintaining team spirit.

The advantages of using JiTT in problem solving learning model can be seen from Table 2. Eight from ten aspects of SPS in the experimental group achieved high to very high category and two other aspects ie the hypothesized (S7) and plan the experiments (S8) were still in the sufficient category. Both hypothesized (S7) and plan the experiment (S8) aspect is lower than the other aspects because the students were still difficulty to determine the dependent variable and the independent variable in designing the experiment, so that student also could not state the relationship of the two variables or state the cause of something happened.

Problem solving learning model based JiTT in the experimental group begins with prelearning webtask, 24 hours before the learning in the class. This task was contained in the lesson plan. The task was given through the web. The task containing issues that will train students' process skills, such as observing, interpreting, planning experiments, etc. So students in the experimental group were better able to apply the concept.

The learning process also evaluated in this present study. The learning process were accessed with student worksheet. The average value of student worksheet per meeting in the experimental group is higher than the control group, because the assigned web tasks make the students better prepared with the material that would be learned. This is in line with previous research which states that web-based tasks encourage students to think about the lessons that will come (Sudarma, 2013).

The mean scores of student worksheets scores in the experimental group at the first, second and third meeting were almost the same that were $83.18,81.91$ and 85.47 . In the final meeting the mean scores of student worksheets 
in the group was 83.52. The decreasing of mean score in second meeting due to the disruption of internet connection. This disruption due to the bad weather that was causing some students lated to complete their web tasks. While the mean scores of student worksheets scores in the control group at the first, second and third meeting were $81.18,79.71$, and 71.88 . Those scores indicate there were the decreasing of students worksheet quality from one meeting to the next. Then, mean score in the final meeting of control group was lower than the experimental group, that was 77.59.

Students' SPS were also observed using observation sheets. The results of the observastion show several aspects of SPS in experiment group were very well empowerd. Those aspects were the questioning aspect (83.33); planning the experiment (91.67), observation (91.67), and communication (91.67). Whereas in the control group there were only two aspects that included the very high category, that were classification (83.33) and communication (83.33). So based on the observation, SPS in the experimental group were better than the control group.

The good score on student worksheets and the good result on SPS observation of the experimental group were influenced by the web task that students did before the classroom learning. The presence of web task in experimental group caused students more understanding about the problems that discussed in classroom. In addition, the task given during web task would prepared the students to face the learning. For example, web task in the second meeting asked students to plan plant tissue observation. Therefpre, when the class begun, the students have already know what to do. Therefore, students could use the time in class efficiently. The implication, there were more time both for students to discuss the experiment result with each other and for teacher to review the learning.

In the control group, student were still difficult to understand the problems presented. Teachers provided more guidance in the control group than in the experimental group, especially during experiments.

The difference between the two groups as a whole was also seen from the learning process. The learning process in the experimental group begins with pre-learning activities 24 hours before the activity of learning in the classroom. Students were given a discourse from the internet that contains a problem on the site that has been determined by the teacher. Then, students compared it with a video. The students also should answer some question related to the problem. When learning in the classroom begun, teacher starts the lesson by clarifying the students' answers. Questions and answers raised in pre-class assignments should be open-ended question, so it could maximize the discussion process in class.

The questions provided in webtask aimed to prepare the students' early knowledge on observing skills, asking questions, planning experiments and other skills before the lesson begins. So students were easier to understand the problems that would be discussed during classroom learning. Whereas in control grou, students have difficulties to understand the problem. Moreover, the students also have difficulties to determine what was known, what they should ask, and how to solve the problem. That were because there was no assignment as in the experimental group. So the teacher gives more direction in solving the problem and takes longer time to be able to apply the material than the experimental group.

The use of JiTT in the experimental group aimed to improve the potency of problem solving learning model as tool that can help teachers to maximize the effectiveness of learning in the classroom. The learning also is hopefully could improve students' readiness on the material will be studied. It can also make learning more interactive and facilitating the efectiveness of student-centered learning in class.

Problem solving allows students to acquire some skills such as observation, discovery, and scientific thinking. The learning model also could train students to collect data, find solutions from problem solving, analyze data and propose a problem-solving. All of those were science process skills (Aka et al., 2010). On the other hand, based on previous research, JiTT could improve student retention, process skills, and mastery of concepts (Mars et al., 2003).

In the present study, the use of problem solving model based on JiTT as a whole could improve student's SPS. From the learnig, students were facililating to apply a concept or material to be studied. Students also observe phenomena used a variety of relevant senses or facts. This activity could train the students to analyze the data and classified it based on 
similarities and differences. Students could also search for the cause of an occurrence and trained to make hypothesis and other skills, until present the results of the observation in oral and written form. In addition, students could interact directly with the learning media, especially when working on webtasks in accordance with the guidance of teachers.

\section{CONCLUSION}

In the study, it could be conclude students' SPS could empower using the problem-solving learning model based JiTT. It can be seen that there were significant difference of postest between experiment and control group, by controlling the pretest score $(\mathrm{F}=4.958 ; \mathrm{p}$ $<0.05)$. Therefore, it is recommended to apply this learning on learning. But, there are some suggestion if teacher is planning to use the learning. Teachers need to prepare the learning very well, because students should complete pre-learning tasks on the web. Teacher also need additional time to simulate JiTT learning, with his students so that the stages of learning can be done well and on time. Teacher also should have backup of files from the web, as anticipation if there are something trouble on internet connection.

\section{REFERENCES}

Fauzi, A., Corebima, A. D., \& Zubaidah, S. (2016). The utilization of ferns as a model organism for studying natural polyploidization concept in genetics course. In International Conference on Education (pp. 51-58). Malang: Universitas Negeri Malang.

Haryono. (2006). Model pembelajaran berbasis peningkatan keterampilan proses sains. Jurnal Pendidikan Dasar, 7(1), 1-13.

Hasanah, H. D. (2014). Analisis keterampilan proses sains siswa kelas XI pada pembeajaran sistem laju reaksi menggunakan model problem solving. Universitas Islam Negeri Syarif Hidayatullah.

Husamah \& Pantiwati, Y. (2014). Cooperative learning STAD-PjBL: Motivation, thinking skills, and learning outcomes in Biology Students. International Journal of Education Learning \& Development (IJELD), 2(1), 7794.

Junaedi, H. S., Supriadi, A. ., Mukhlison, \& Mustamin. (2008). Strategi pembelajaran. Surabaya: Lapis-PGMI.

Mars, K. A., Blake, R. E., \& Gavrin, A. D. (2003). Use Warm up exsercises in just in time teaching to determine students prior knowledge and misconseptions in biology, chemistry, and physics. US: Indianapolis.

Prawiradilaga, D. S., Ariani, D., \& Handoko, H. (2013). Mozaik teknologi pendidikan elearning. Jakarta: Kencana.

Solikhin, J. R. (2013). Model pembelajaran just in time teaching (JiTT) untuk meningkatkan keterampilan proses sains siswa SMP pada materi hukum newton. In Prosiding Seminar Nasional Sains dan Pendidikan Sains VIII. Salatiga: Fakultas Sains dan Matematika UKSW.

Sudarma, T. F. (2013). Efek model pembelajaran kooperatif tipe STAD berbasis just in time teaching terhadap hasil belajar fisika pada mata kuliah fisika sekolah di jurusan fisika FMIPA UNIMED. Jurnal Online Pendidikan Fisika, 2(1), 9-16.

Sugiyono. 2013. Metode penelitian kuantitatif kualitatif dan R \& D. Bandung: Alfabeta.

Susilowati. (2013). Membelajarkan IPA dengan integrative science tinjauan scientific process skills dalam implementasinya pada kurikulum 2013. In Prhantoro (Ed.), Prosiding Seminar Nasional Penelitian, Pendidikan dan Penerapan MIPA (pp. 95103). Yogyakarta: Fakultas MIPA UNY.

Zulfiani, Feronika, T., \& Suartini, K. (2009). Strategi pembelajaran sains. Jakarta: LPU Jakarta. 